Technologia"Vol 11, No. 2, April-Juni 2020

\title{
PEMANFAATAN MOBILE PUSH NOTIFICATION DALAM PENYAMPAIAN INFORMASI PERKULIAHAN MAHASISWA PADA FAKULTAS TEKNOLOGI INFORMASI BERBASIS ANDROID
}

\author{
Muharir ${ }^{1)}$, Nur Alamsyah ${ }^{2)}$ \\ ${ }^{l}$ Fakultas Teknologi Informasi, Universitas Islam Kalimantan Muhammad Arsyad Al Banjari Banjarmasin \\ Email: muharir17@gmail.com \\ ${ }^{2}$ Fakultas Teknologi Informasi, Universitas Islam Kalimantan Muhammad Arsyad Al Banjari Banjarmasin \\ Email: uniskalam@gmail.com
}

\begin{abstract}
ABSTRAK
Pesatnya perkembangan teknologi saat ini menyebabkan kebutuhan akan data atau informasi dituntut disajikan secara cepat dan mudah untuk diakses. Informasi yang disajikan dalam bentuk website memang sudah menjawab sebagian penyajian informasi yang lengkap. Namun di era mobile saat ini, memungkinkan pengaksesan data atau informasi yang lebih praktis, cepat, murah dan efesien. Pendistribusian informasi yang baik telah menjadi kebutuhan yang penting untuk menunjang kegiatan perkuliahan dan belajar-mengajar di Fakultas Teknologi Informasi Uniska.

Fakultas Teknologi Informasi saat ini mendistribusikan informasi perkuliahan melalui media Website dan jejaring sosial seperti instagram, whats'app, juga mading fakultas. Namun hal ini dirasa belum cukup untuk pendistribusian informasi yang cepat dan efektif, hal ini dibuktikan dengan adanya sebagian mahasiswa yang tidak mengetahui informasi terbaru yang disampaikan pihak fakultas.

Informasi yang disampaikan melalui website atau sosial media mengharuskan mahasiswa menginstall banyak aplikasi lalu masuk pada group tertentu, selain itu mahasiswa juga masih disibukkan dengan memilah informasi terbaru dengan melihat tanggal postingan group.
\end{abstract}

Kata kunci: Sistem Informasi, Data, Push Notification.

\section{PENDAHULUAN}

Salah satu aplikasi nyata yang dapat dilihat di masyarakat adalah penggunaan telepon genggam (smartphone) sebagai sarana komunikasi utama bagi mayoritas individu. Peningkatan penggunaan telepon genggam juga selaras dengan meningkatnya pengembangan aplikasi berbasis mobile. Sebagai contoh, menurut survei yang dilakukan oleh Comscore di Amerika Serikat, jumlah aplikasi berbasis mobile telah meningkat sebesar 90\% selama tiga tahun terakhir (2015-2018).

Hal ini terjadi karena aplikasi berbasis mobile lebih interaktif, dibandingkan dengan website ataupun media lainnya. Salah satu fitur unggulan yang membuat aplikasi berbasis mobile menjadi interaktif adalah fitur push notification.
Fitur push notification memungkinkan sistem untuk dapat memberikan notifikasi kepada user walaupun user tidak sedang mengakses aplikasi berbasis mobile tersebut. Platfom penyedia push notification saat ini yaitu, One Signal dan FCM. Pada penelitian ini dipilih One Signal dikarenakan dokumentasi yang lengkap dan unlimited resource push notification yang di berikan untuk notifikasi pada mobile android. Sedangkan FCM fiturnya terbatas dan berbabayar karena target fcm adalah korporasi dan perusahaan skala besar.

Fakultas Teknologi Informasi adalah salah satu Fakultas yang ada di Universitas Islam Kalimantan. Fakultas ini memiliki dua program studi yaitu program studi Teknik Informatika dan Sistem Informasi. Fakultas Teknologi Informasi (FTI) memiliki mahasiswa yang lumayan banyak, dengan 
jumlah dosen sekitar 70 orang. Saat ini saja jumlah mahasiswa Teknik informatika sampai periode semester 2018/2019 sebanyak 4.419 mahasiswa, sedangkan program studi Sistem Informasi memiliki mahasiswa sebanyak 470 orang atau dapat dilihat pada tabel dibawah ini:

\begin{tabular}{|c|l|c|c|c|c|}
\hline No & \multicolumn{1}{|c|}{ Prodi } & $\begin{array}{c}\text { Mahasiswa } \\
\text { Aktif }\end{array}$ & Pindahan & Cuti & $\begin{array}{c}\text { Mahasiswa } \\
\text { Non Aktif }\end{array}$ \\
\hline $\mathbf{1}$ & Teknik Informatika & 4.419 & 363 & 7 & 0 \\
\hline $\mathbf{2}$ & Sistem Informasi & 470 & 96 & 0 & 0 \\
\hline & Jumlah & 4.889 & 459 & 7 & 0 \\
\hline
\end{tabular}

Sumber : sia online uniska

Dalam penyampaian informasi kepada mahasiswa, fakultas telah menggunakan berbagai cara antara lain melalui media cetak, sosial media, sms gateway, dan website, akan tetapi website ataupun smsgateway yang saat ini digunakan masih belum mendukung sebagai sebuah sistem informasi yang dapat memenuhi akan informasi yang cepat, mudah, dan murah dalam pengaksesannya bagi seluruh mahasiswa, lebih khususnya lagi mahasiswa baru. Aplikasi berbasis mobile yang dikombinasikan dengan fitur push notification diharapkan dapat memberikan manfaat yang besar dalam suatu sistem distribusi informasi, tidak terkecuali untuk sistem distribusi informasi di dalam dunia pendidikan, khususnya di Fakultas Teknologi Informasi UNISKA.

\section{METODE PENELITIAN}

Dalam penelitian ini ada beberapa metode dalam memperoleh data. Adapun metode yang dilakukan dalam mengumpulkan data, yaitu sebagai berikut:

1. Metode Pengamatan (Observasi) : Dengan metode ini bisa langsung mengamati kegiatan yang sedang berlangsung didalam Fakultas Teknologi Informasi bagaimana proses penilaian terhadap judul-judul yang telah diajukan.

2. Metode Wawancara (Interview) : Dengan metode ini bisa berdialog secara tanya langsung kepada Kaprodi Teknik Informatika dan Sistem Informasi beserta Dekan Fakultas Teknologi Informasi

3. Studi Pustaka dan Studi Dokumentasi; ini dilakukan dengan cara mempelajari, meneliti dan menelaah berbagai literaturliteratur dari perpustakaan yang bersumber dari buku-buku, teks, jurnal ilmiah, situs-situs di internet, dan bacaanbacaan yang ada kaitannya dengan topik penelitian.

\section{Tahapan Pengembangan Perangkat} Lunak.

Kemudian untuk metode pengembangan sistem perangkat lunak mengacu pada model waterfall adalah salah satu model pengembangan software, dimana kemajuan suatu proses dipandang sebagai terus mengalir ke bawah seperti air terjun. Dalam Model Waterfall, setiap tahap harus berurutan, dan tidak dapat meloncat ketahap berikutnya, harus menyelesaikan tahap pertama baru lanjut ke tahap ke dua dan seterusnya.

Langkah-langkah model waterfall dapatdilihat pada gambar dibawah Ini:

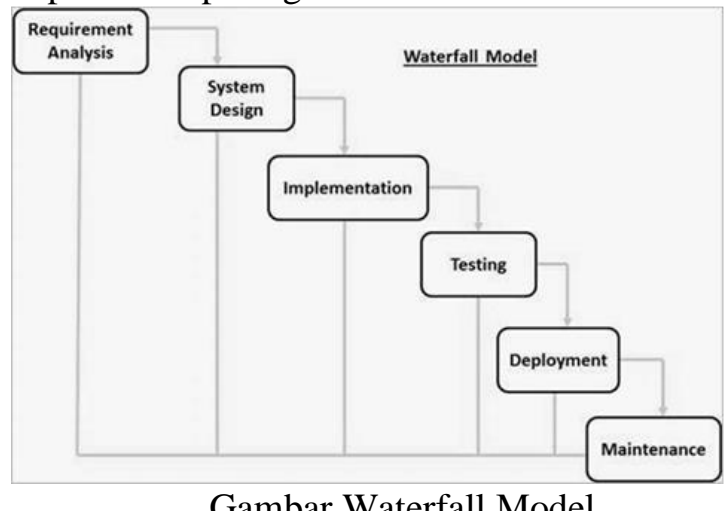

Gambar Waterfall Model

\section{Requirement Gathering and analysis}

Tahap requirement atau spesifikasi kebutuhan sistem adalah Mengumpulkan kebutuhan secara lengkap kemudian kemudian dianalisis dan didefinisikan kebutuhan yang harus dipenuhi oleh program yang akan dibangun. Fase ini harus dikerjakan secara lengkap untuk bisa menghasilkan desain yang lengkap.

\section{Sistem Design}

Tahap selanjutnya adalah design, desain dikerjakan setelah kebutuhan selesai dikumpulkan secara lengkap.

\section{Implementation}

Selanjutnya tahap implementasi, yaitu desain program diterjemahkan ke dalam kode-kode dengan menggunakan bahasa pemrograman yang sudah ditentukan. Program yang dibangun langsung diuji baik secara unit. 


\section{Integration and Testing}

Penyatuan unit-unit program kemudian diuji secara keseluruhan (sistem testing)

\section{Deployment of Sistem}

Mengoperasikan program dilingkungannya dan melakukan pemeliharaan, seperti penyesuaian atau perubahan karena adaptasi dengan situasi sebenarnya.

\section{Maintenance}

Proses pemeliharaan sistem yang sudah dibangun.

\section{Rancangan Model Sistem}

Perancangan model sistem adalah merancang atau mendesain sistem yang baik, isinya adalah langkah-langkah operasi dalam pengolahan data dan prosedur untuk operasi sistem. Kegiatan yang dilakukan pada tahap ini yaitu merancang atau mendesain sistem yang baik, mendesain pemodelan sistem yang baik, mengenali dan mendefinisikan masalah pembuatan sistem ini sehingga jika ada kesalahan ada alternatif pemecahannya.

\section{Arsitektur Sistem}

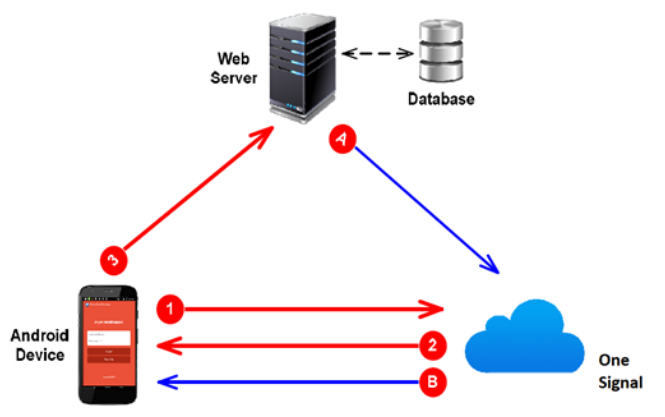

Gambar 2 Arsitektur Sistem

Perancangan model sistem adalah merancang atau mendesain sistem yang baik, isinya adalah langkah-langkah operasi dalam pengolahan data dan prosedur untuk operasi sistem. Kegiatan yang dilakukan pada tahap ini yaitu merancang atau mendesain sistem yang baik, mendesain pemodelan sistem yang baik, mengenali dan mendefinisikan masalah pembuatan sistem ini sehingga jika ada kesalahan ada alternatif pemecahannya.

\section{Use Case Diagram}

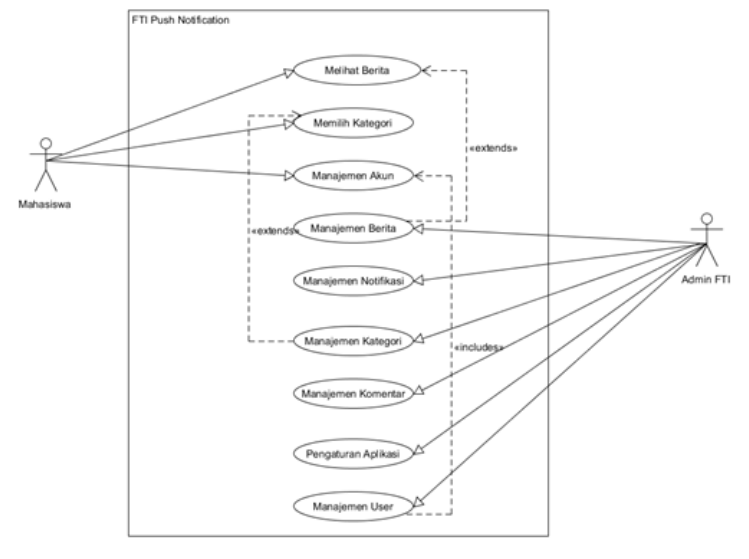

\section{Rancangan Tabel}

Berikut rancangan tabel data-data dalam perancangan Pemanfaatan Mobile Push Notification Dalam Penyampaian Informasi Perkuliahan Mahasiswa Pada Fakultas Teknologi Informasi Berbasis Android, yaitu:

1) Tabel tbl_admin

2) Tabel tbl_category

3) Tabel tbl_comments

4) Tabel tbl_fcm_template

5) Tabel tbl_fcm_token

6) Tabel tbl_news

7) Tabel tbl_news_gallery

8) Tabel tbl_settings

9) Tabel tbl_users

\section{Rancangan Antarmuka}

Rancangan antarmuka masukan sistem berfungsi untuk menjelaskan tentang perancangan aplikasi yang akan dibangun. Hal ini dilakukan untuk mempermudah pengguna dalam mengetahui proses yang terdapat pada aplikasi yang akan dibangun. Untuk lebih jelasnya rancangan antarmuka masukan sistem dapat dilihat dibawah ini.

\section{Antarmuka WEB}

1. Rancangan Login Sistem

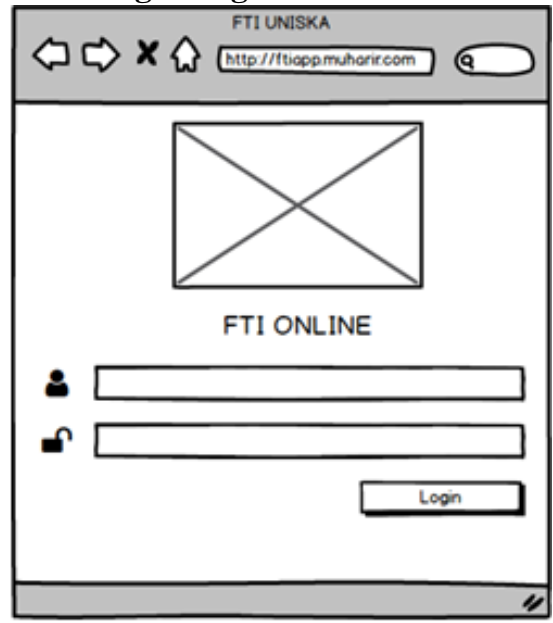




\section{Dashboard}

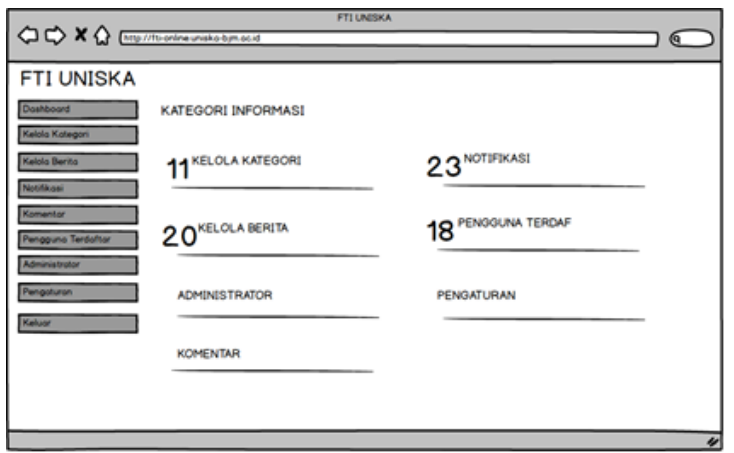

\section{Kelola Berita}

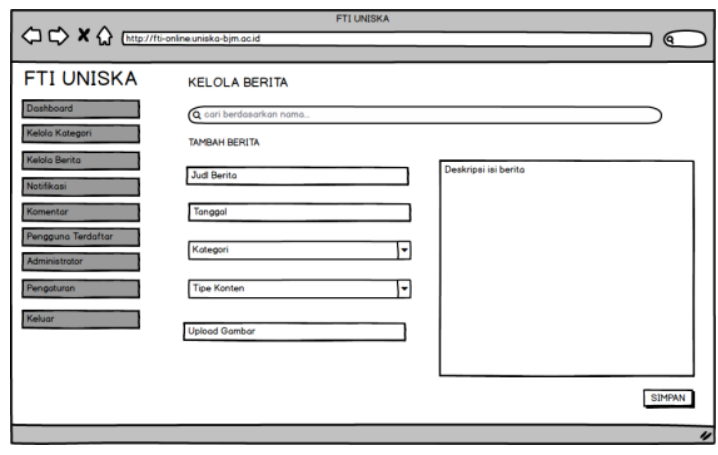

\section{Kelola Kategori}

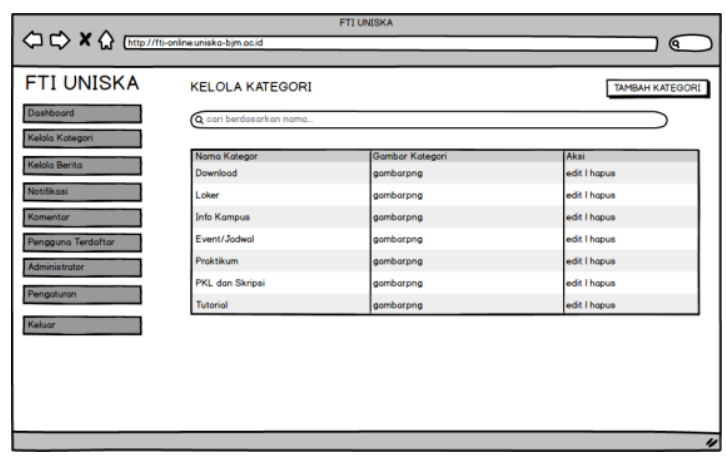

\section{Kelola Komentar}

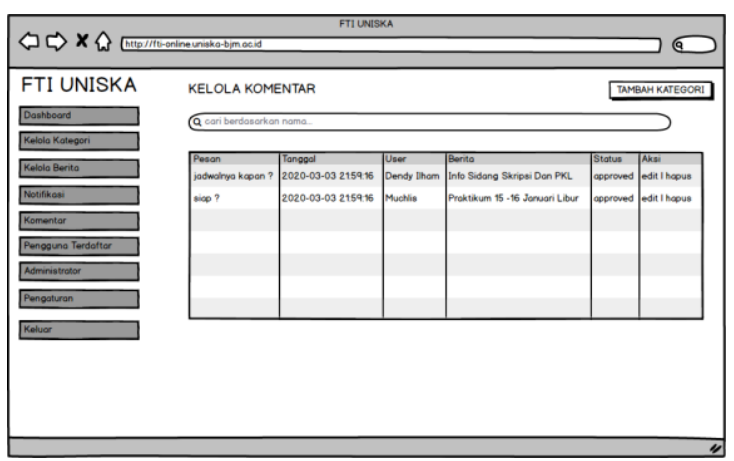

\section{Kelola Notifikasi}

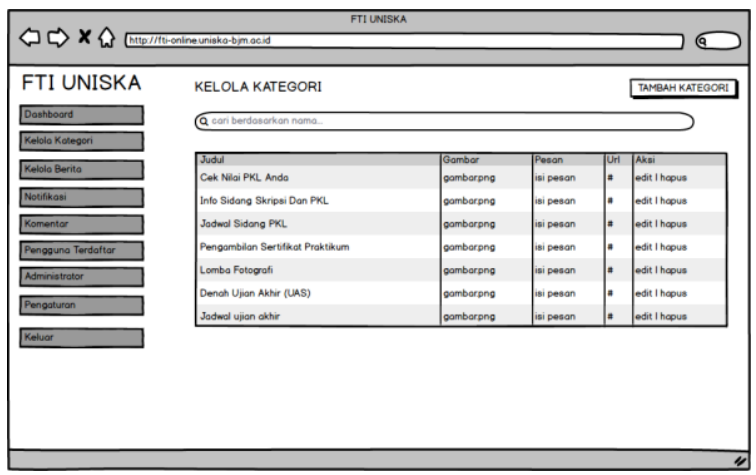

\section{Antarmuka Mobile}

1. Menu Utama

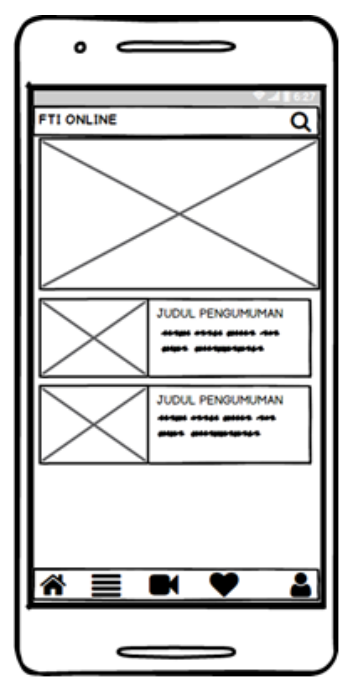

2. Login

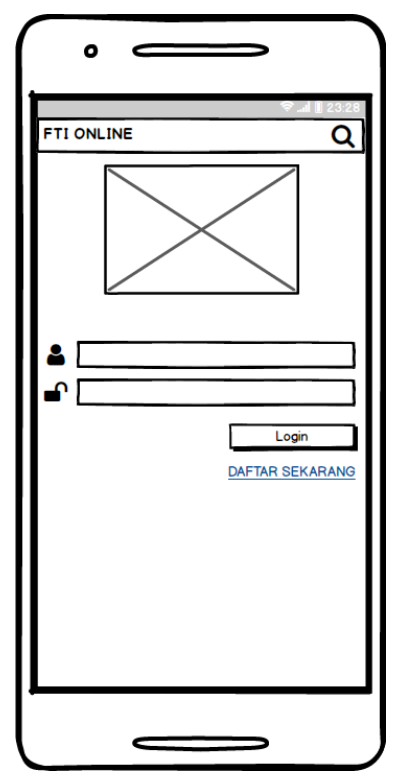




\section{Register}

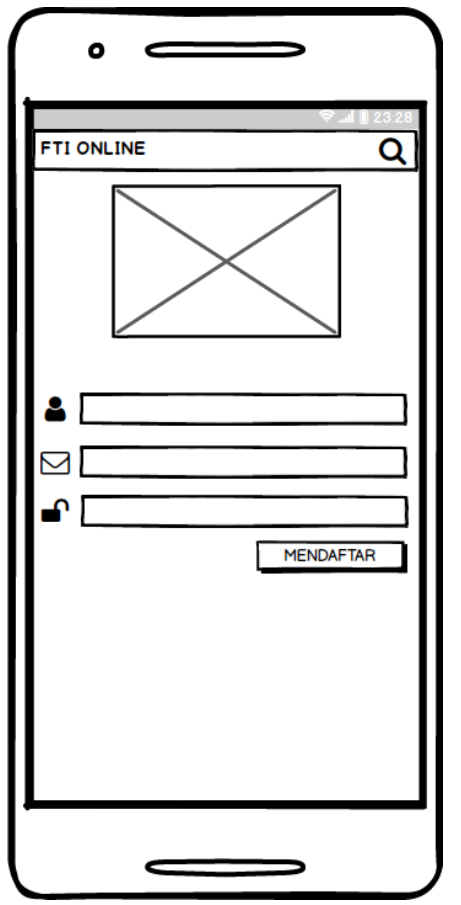

\section{Detail Berita}

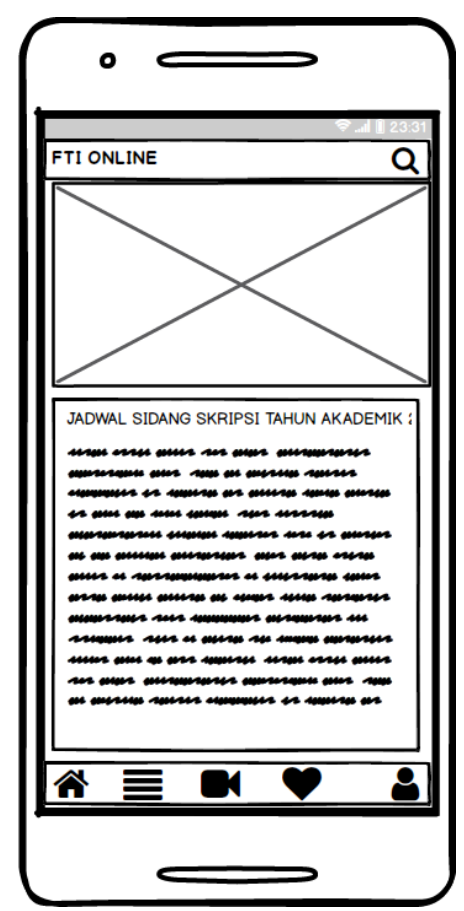

\section{HASIL DAN PEMBAHASAN}

\section{Implementasi}

Implementasi adalah tahapan ketiga dalam pembuatan software menggunakan metode Waterfall. Pada tahap ini semua tahapan sebelumnya baik dari perancangan table dan mockup yang ada mulai di implementasikan dengan penulisan kode-kode program. Berikut beberapa antarmuka program yang telah dibuat :

Implementasi Pada Web

\section{Tampilan Login}

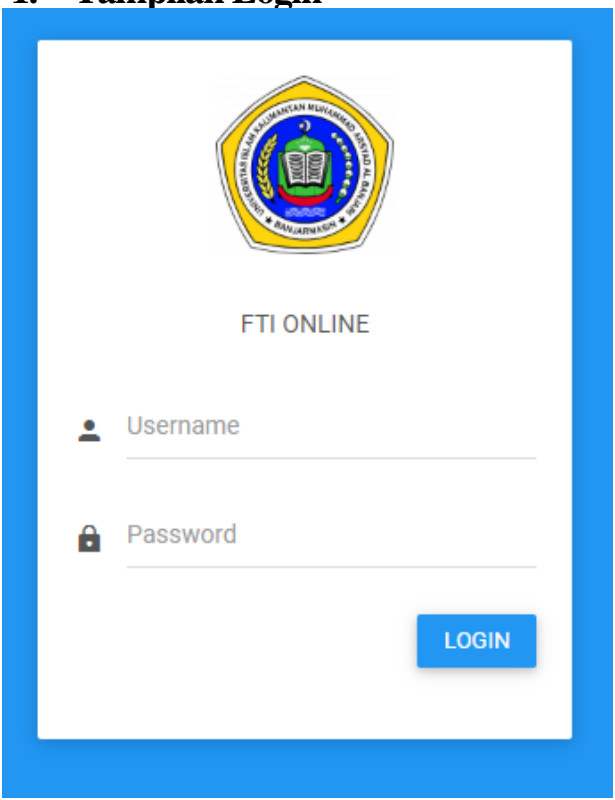

\section{Tampilan Dashboard}

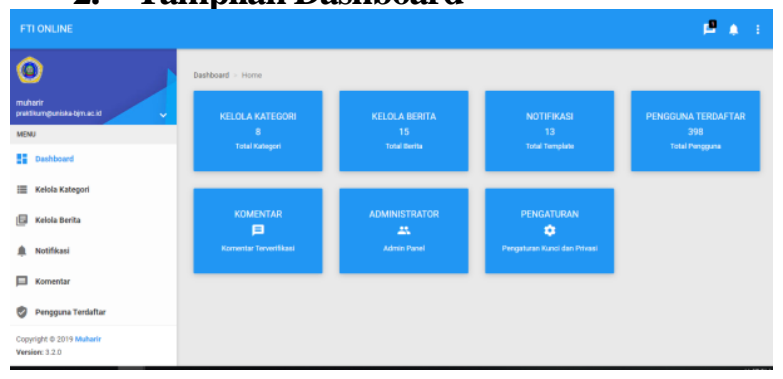

\section{Kelola Berita}

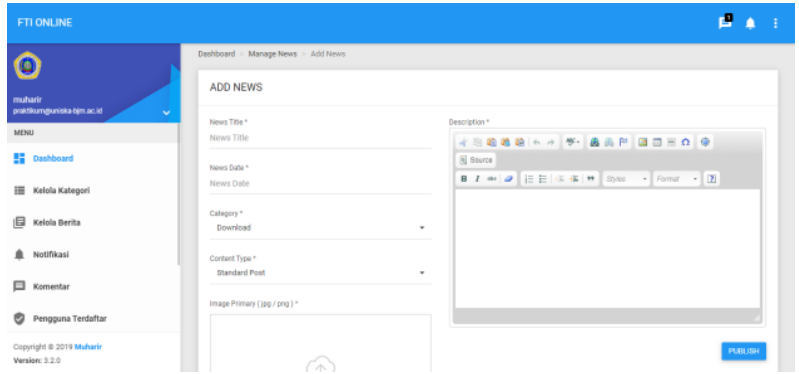




\section{Kelola Kategori}

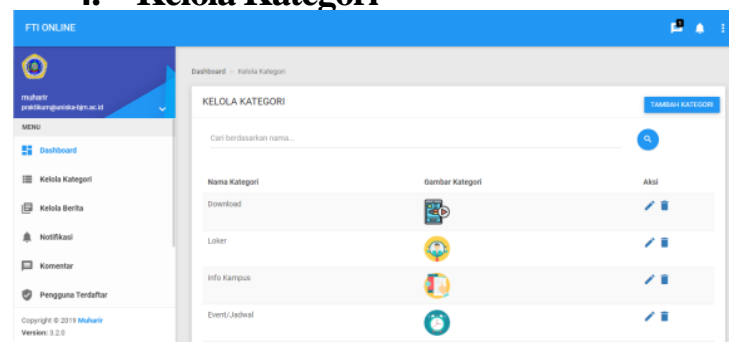

\section{Kelola Notifikasi}

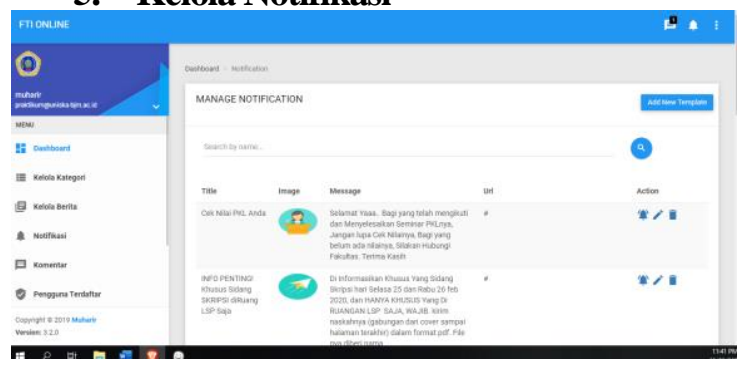

\section{Kelola Komentar}

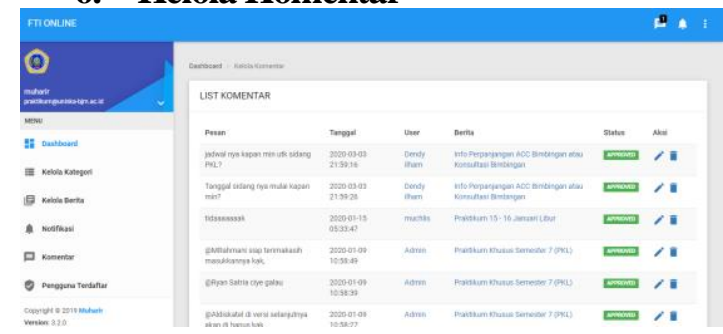

\section{Implementasi Pada Mobile}

1. Login

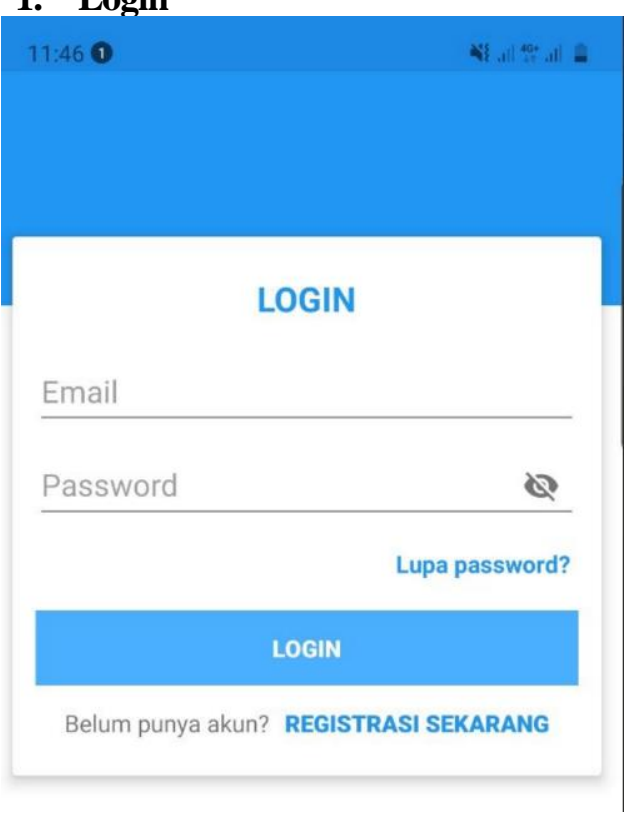

\section{Register}

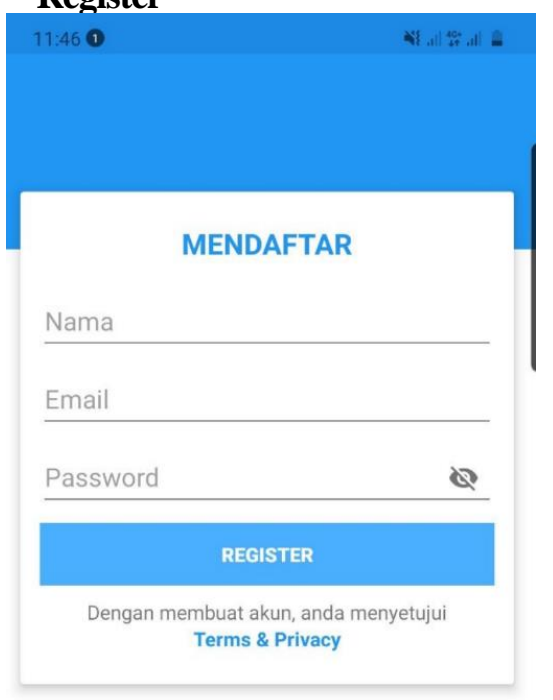

\section{Menu Utama}
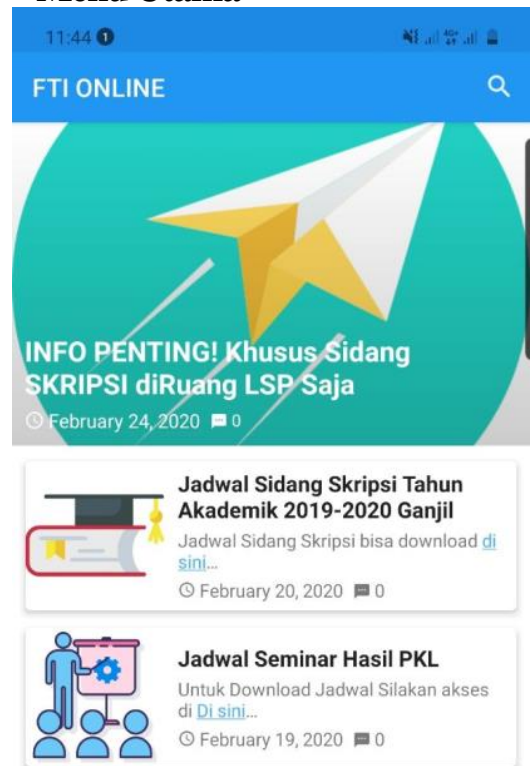

February 20, $2020 \mathrm{~m}$

Jadwal Seminar Hasil PKL Untuk Download Jadwal Silakan akses di Di sini.

(c) February 19, 2020 =

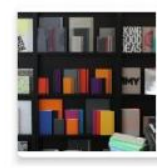

Info Jadwal Seminar PKL dan Sidang Skripsi T.A 2019-2020 UNTUK SEMINAR HASIL PKL:

(9) February 18, 2020 =0

Sertifikat Praktikum Khusus Semester 7 (PKL)

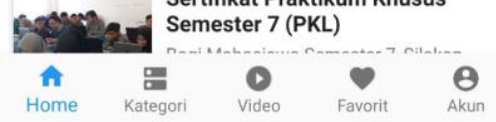




\section{Detail Berita}

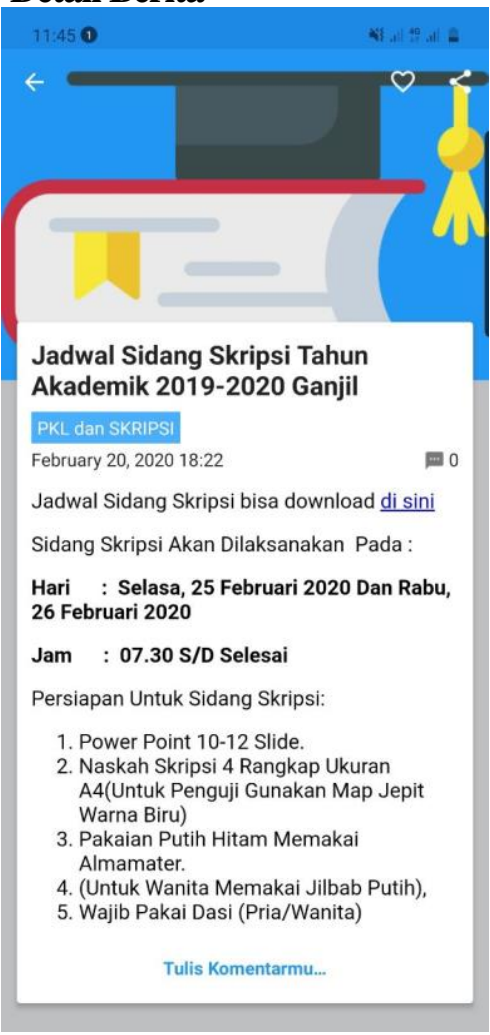

\section{Kategori}
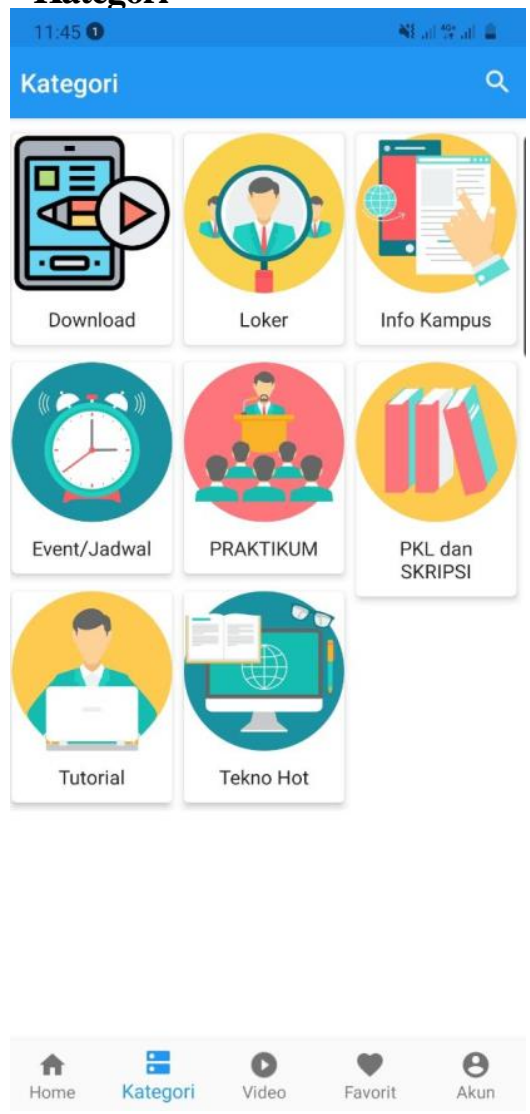

\section{KESIMPULAN DAN SARAN}

Berdasarkan hasil dari analisis, perancangan dan implementasi dari penelitian dapat disimpulkan sebagai berikut:

1. Pemanfaatan Mobile Push Notification Dalam Penyampaian Informasi Perkuliahan Mahasiswa Pada Fakultas Teknologi Informasi Berbasis Android dapat diterapkan dengan baik.

2. Aplikasi yang dibuat mudah digunakan baik oleh admin maupun user (mahasiswa).

3. Dengan adanya aplikasi ini penyampaian informasi-informasi kepada mahasiswa langsung dapat mereka ketahui melalui Handphone mereka sehingga tidak ketinggalan informasi penting.

Saran yang dapat diberikan untuk penelitian selanjutnya adalah menambah fitur-fitur forum komunikasi antar mahasiswa dengan admin atau fakultas selain menggunakan komentar yang sudah terdapat pada aplikasi.

\section{REFERENSI}

Safaat, Nasruddin. 2012. Pemrograman Aplikasi Mobile Smartphone dan Tablet PC Berbasis Android. Bandung: Informatika Bandung.

Pressman, Roger S. (2002). Rekayasa Perangkat Lunak (Pendekatan Praktisi Buku Satu).Edisi keempat.Yogyakarta: Andi

Barata. 2014. Sistem Informasi Akademik Laboratorium Kimia Dasar. Skripsi. Program Studi Ilmu Komputer FMIPA UGM. Yogyakarta.

Basuki, A., P. 2010. Membangun Framework Berbasis PHP dengan Framework CodeIgniter. Penerbit Lokomedia. Yogyakarta.

Benedetti, R. Dan Cranley, R. 2011. Head First jQuery, O’Reilly Media, Inc.

Cochran, D. 2012. Twitter Bootstrap Web Development How-To. PACKT Publiseher.

Date, C. 2002. An Introduction to Database System, Sevinth Edition. New York: Addison- Wesley Publishing Company.

Demiawansyah, A. 2014. Sistem Informasi Persiapan Praktikum di Program Studi 
Komputer dan Sistem Informasi SV UGM. Tugas Akhir. Program Studi Komputer dan Sistem Informasi SV UGM. Yogyakarta.

Dennis, A., Wixom, B., \& Roth, R. 2009. System Analysis and Design. John Wiley and Sons Inc.

Jogiyanto. 2005. Analisis dan Desain Sistem Informasi: Pendekatan Terstruktur Teori dan Praktik Aplikasi Bisnis. Yogyakarta: Penerbit Andi.

Kossiakof. 2002. System Engineering Principles and Practice. John Wiley and Sons Inc.

Laksono. 2013. Aplikasi Penjadwalan Perkuliahan Praktikum Berbasis Web di Pusat Laboratorium Terpadu UIN Syarif. Skripsi. UIN Syarif. Jakarta.

Mansfield, R. 2005. CSS Web Design For Dummies. John Wiley and Sons, Inc.

Mc Farland, D. 2013. CSS3: The Missing Manual. O'Reilly Media, Inc.

Mc Farland, D. 2009. Javascript and Query: The Missing Manual, Second Edition. O'Reilly Media, Inc.

Nixon, R. 2009. Learning PHP, MySQL and Javascript. O'Reilly Media, Inc.

Powell, T. 2010. HTML and CSS: The Complete Reference, Fifth Edition. The McGraw- Hill Companies, Inc.

Powers, D. 2012. Beginning CSS3: Mastering The Language of Web Design. Apress. 